\title{
How Should You Perform and Watch Othello and Hairspray in a Country Where You Could Never Hire Black Actors? Shakespeare and Casting in Japan ${ }^{1}$
}

\begin{abstract}
This paper discusses how Japanese theatres have handled race in a country where hiring black actors to perform Shakespeare's plays is not an option. In Englishspeaking regions, such as the United States and the United Kingdom, it is common to hire a black actor for Othello's title role. Blackface is increasingly unacceptable because it reminds viewers of derogatory stereotypes in minstrel shows, and it deprives black actors of employment opportunities. However, the situation is different in regions where viewers are unfamiliar with this Anglo-US trend. In Japan, a country regarded as so homogeneous that its census does not have any questions about ethnicity, it is almost impossible to hire a skilled black actor to play a title role in a Shakespearean play, and few theatre companies would consider such an idea. In this cultural context, there is an underlying question of how Japanese-speaking theatre should present plays dealing with racial or cultural differences. This paper seeks to understand the recent approaches that Japanese theatre has adopted to address race in Shakespearean plays by analysing several productions of Othello and comparing them with other major non-Shakespearean productions.
\end{abstract}

Keywords: Japan, Blackface, Othello, Hairspray, Memphis, Ainu, Fandom, Social media.

In English-speaking regions like North America and the British Isles, racially diverse casting has become increasingly prevalent. It is now common to hire a black actor for Othello's title role, while blackface has become rare because it

* Musashi University.

1 This paper is partly based on the oral presentation "How Should You Perform and Watch Othello in a Country Where You Could Never Hire Black Actors? Shakespeare and Casting in Japan," given on 7 August 2018 at the Wooden O Symposium at Southern Utah University. It is part of the project supported by JSPS KAKENHI Grant Number 19K13117. This paper is also benefited from the discussion of the students in my 2018 seminar, especially Iijima Hiroki-san. 
reminds viewers of derogatory stereotypes from minstrel shows and deprives black actors of employment opportunities. Although the performance history of Othello is filled with white actors with blackface, by the late 1990s most highprofile English productions of the play came to hire black actors for the title role (Holland 206: Suematsu; Vaughan 2). Even in opera, where blackface is still used, New York's Metropolitan Opera abandoned this practice in its 2015 Otello (André 9-11).

However, the situation is different in less racially diverse regions like Japan, where audiences are unfamiliar with this trend. In the United States, as of 1 July $2019,76.3 \%$ of the population was classified as "white," $18.5 \%$ as "Hispanic or Latino," and 13.4\% as "Black or African American" (United States Census Bureau). According to the 2011 census in England and Wales, 86\% of the population was "white", 7.5\% "Asian", and 3.3\% "Black" (Office for National Statistics). By contrast, Japan's homogeneity is so deeply entrenched that its census asks no questions about race or ethnicity. According to Japan's Immigration Services Agency, 2.24\% of the Japanese population in June 2019 were non-Japanese nationals, although this figure deals with nationalities rather than ethnic backgrounds. Among these non-Japanese residents, 27.8\% were Chinese and 16\% Korean (Immigration Services Agency). Those coming from African countries are referred to as "the minority of the minority ${ }^{2}$ ". Demographically, Japan is less diverse than the USA and the UK, with ethnically Japanese people forming an overwhelming majority of the population. This means that Japanese theatres can rarely hire black actors; some may even be unaware that such an option exists. ${ }^{3}$

Japanese companies have a higher bar when tackling race in Shakespeare's plays because few audience members have given thought to the reality of racism in a more diverse society. Theatre companies have difficulty finding black actors, and most audience members are unfamiliar with the current concept of race discussed and questioned in North America and Europe. Ayanna Thompson, analysing Asian American YouTube performances of Shakespeare's plays, points out that they "update Othello's narrative by framing it in a fantasy of contemporary, black-American culture" (18). However, in Japan this option is unavailable because, unlike American audiences, Japanese audiences do not have a unified "fantasy of contemporary, black-American culture" typified by gangsta rap. Japanese theatres must come up with new solutions to interpret racial differences for their audience.

2 Matsumoto 1. All Japanese quotations are translated by the author.

3 Because of the rarity of black actors in Japan, in 2018 Theodore Adams III directed 'Othello-san', a short film about a fictional African American actor starring in a Japanese production of Othello. 
One could come up with an idea of casting minority actors for black roles such as Othello, but it is rarely a viable option for Japanese companies. As Baye McNeil, an African-American writer living in Japan, suggests, no Japanese Shakespeare company has yet hired a black actor for Othello because it is difficult to find one, although he hopes that such a production will be possible in the near future (McNeil). Furthermore, casting minority actors could make a production even more problematic. Japan is not so homogeneous as it appears, and most visible ethnic minorities are Korean, Chinese, Ainu, Ryukyuan, and the outcast class called burakumin. Although these groups are clearly racialized, and racializing discourses historically draw on purported physical differences (Kurokawa 62), there is little difference between these minority groups and ethnically "Japanese" people in appearance. Almost all these people have dark hair and eyes, with skin colour ranging between brownish yellow and smoky white. Minority actors from these groups can easily pass as "Japanese." A Japanese audience may thus have watched a minority actor playing Othello without even realising it. If a company hires a minority actor as Othello and advertises that as a point of the production, that act may be considered a kind of racial "outing."

Given this problematic situation, Japanese theatre companies have tried to address the issue by culturally translating Othello into the Japanese context. They have adopted several interpretive strategies, such as shifting the focus from racism to lookism, using different acting styles to represent racial otherness, and highlighting racism in Japan by changing Othello's race. This paper discusses how Japanese theatres have handled race in a country where hiring black actors to perform Shakespeare's plays is not an option. The first section of the paper focuses on the Japanese blackface tradition in general and its use in theatre, because without understanding the cultural context, it is impossible to analyse the performance history of Shakespeare's so-called "race plays" in Japan. Several non-Shakespearean performances are also discussed, which helps to reveal the general casting trends. The second section analyses current Shakespearean productions by Japanese theatres and their attempts to address race, focusing largely on three productions of Othello by the Setagaya Public Theatre, Kakushinhan, and the Shakespeare Company in Sendai, with references to other related productions.

\section{The Recent History of Blackface and Theatre in Japan}

Thanks to American influence, Japan has a long tradition of blackface. American minstrel shows reached Japan when it first opened up to the West after over 220 years of isolation. When Commodore Matthew C. Perry arrived in Japan in 
1854, "An Ethiopian entertainment ${ }^{4}$ ", or minstrel show, was performed for Japanese guests on board the Powhatan. This show served as "a powerful facilitator of US-Japan solidarity" (Bridges 2).

Since that first contact, blackface has appeared in Japanese theatre, films, and TV shows. Comedians and musicians of the 1930s adopted blackface in singing (Sato 65). "Spider and Tulip", a 1943 short animated film by Masaoka Kenzo, depicts a blackface spider as a villain, perhaps influenced by Disney films (Hagihara 6). The most striking use of blackface in Japanese culture is found in African American music communities. Rats \& Star, a Japanese doowop group popular in the 1980s, wore blackface, and Andy Warhol designed the sleeve of their 1983 album Soul Vacation, with the members' blackface portraits prominently featured.

In the Japanese context, performers traditionally wore blackface as a symbol of enthusiastic respect for African American culture and artistic rebelliousness. Few Japanese viewers noticed its racist connotations because it had been completely separated from its original history. People from the United States introduced blackface to Japan, but its cultural and historical baggage was left back there. However, racial discrimination toward black people does exist in Japan. A recent psychological research suggests a "relative implicit preference of "white people" over "black people"" in Japanese society (Mori 7), but this bias remains largely unnoticed, which makes it difficult for the viewers to understand the problematic nature of blackface. With little knowledge of its historical background, Japanese audiences received it as something typically American in the process of globalisation.

This changed in the mid-2010s, when Japan faced another phase of globalisation in the age of social media. In 2015, Rats \& Star members collaborated with the female idol group Momoiro Clover $\mathrm{Z}$ for a television show; before the broadcast, they published a photo online in which the two groups wore blackface, as Rats \& Star had done in the 1980s. Social media was soon filled with criticism, and this plan was withdrawn, partly due to a protest led by McNeil (Osaki). In 2018, Hamada Masatoshi, a member of the popular Japanese comedy duo Downtown, appeared on television dressed as Eddie Murphy. His blackface makeup was controversial and made headlines in English media, including the "Japanese TV Show Featuring Blackface Actor Sparks Anger". However, not many Japanese viewers understood the nature of the problem, and much of the criticism came from American residents in Japan ("Japanese TV Show Featuring Blackface Actor Sparks Anger"; Suzuki and Allen).

${ }^{4}$ See the reproduction of the show's program, partly available online at the International Fellowship of Regional Music and Culture's website (http://rmac.jp/motion/ motion02.html); see also Yellin 266-267. 
Part of the reason why the Japanese blackface tradition has remained unquestioned until recently is the small black population in Japan. It has been impossible for most theatres to hire skilled black actors to play Shakespearean title roles in Japanese. Indeed, virtually no company would consider the idea.

Until around 2010, blackface was common in Japanese Shakespeare productions. Hira Mikijiro, a well-known actor in Japan, played Othello many times; according to Mainichi Shimbun's article in 1973, he took his blackface makeup seriously, even appearing at early rehearsals wearing it ("Ambitious for the 'Black Transformation"'). On the 1995 and 2006 posters for the Othello productions, he wore blackface. When Sato Chikau played Othello for the Shakespeare for Children project in 1999, he said, "since I am naturally darkskinned, I won't paint my face black" (Kodama). Even though blackface gradually came to be avoided in Othello, blackness itself was still considered necessary. In twenty-first-century Japanese theatre, the idea that black characters should be dark-skinned remains, but a more modest "blacking up" is preferred to stereotypical blackface. When Yoshida Kotaro played Othello in Ninagawa Yokio's 2007 production, he appeared as a naturally dark-skinned, suntanned general.

There are several striking non-Shakespearean examples of blacking up in Japan. Memphis, a musical about interracial romance between Huey, a white DJ, and Felicia, an African American singer in the 1950s, was performed at Tokyo's New National Theatre in 2015 and 2017. The productions were choreographed and directed by the African American artist Jeffrey Page, with Yamamoto Koji, a Japanese actor who played Huey, joining as co-director in 2017. A popular Japanese African American singer, Jero, played Felicia's brother Delray, while Felicia was played by a Japanese actress, Hamada Megumi. As noted above, it is difficult for Japanese companies to hire black actors, but Memphis was able to do so, because it was a big-budget musical; notably, even in such a high-profile effort, the creative team could not find enough black actors to play all the African American characters. In this production, many of the actors who played African American characters blacked up. In an interview, Page said that he tried to avoid blackface because it was unacceptable in the United States (Gekipia Editorial Desk). However, according to another interview with the actors and a post-show talk on 3 December 2017, they finally decided to black up modestly, because the Japanese audience would have otherwise had difficulty understanding the show. ${ }^{5}$ Even though the cast and crew included multiple African American artists, the Japanese theatrical

5 See Enterstage Editorial Desk's article. The content of the post-show talk was not officially published, but a detailed report with analysis was uploaded in a theatre review blog by a fan with the username "aru" at http://ayayay.cocolog-nifty.com/ blog/2017/12/2-5284.html 
production still had to adopt dark makeup. Behind this decision is the notion that Japanese society is so homogeneous that a Japanese audience would not understand racial differences unless they were clearly visible.

If an actor chose to adopt more traditional blackface than modest blacking up, the production would likely be criticised, although the problem would be unnoticed by mainstream media. From June to July 2019, Driving Miss Daisy was staged in Kinokuniya Hall. This production was directed by Mori Shintaro, a director experienced in various classic playwrights, including Shakespeare. Ichimura Masachika, who has starred in a wide variety of productions ranging from musicals to Shakespeare, wore traditional blackface to play Hoke, Daisy's African American chauffeur. As soon as the publicity photos were published, this decision was heavily criticised on the web as outdated. ${ }^{6}$ For example, Maruya Kyubee, an expert on African American music, stated that it was an "anachronistic" and "destructive" theatrical choice. However, mainstream theatre reviews rarely discussed the issue. When the production made the $27^{\text {th }}$ Yomiuri Theatre Award shortlist, one reviewer commented on Driving Miss Daisy without mentioning blackface: "I have rarely seen a recent production with a better aftertaste than this" ("The $27^{\text {th }}$ Yomiuri Theatre Award Screening Meeting"). The use of blackface did not affect the reviewer's "aftertaste" of the production.

The Takarazuka Revue, an all-female musical company in Hyogo, has a long history of using both stereotypical blackface and the less extreme blacking up. Otokoyaku, or female performers specialising in male roles, use red or brownish greasepaint to look more "masculine" even when they play white male roles, while musumeyaku, actresses specialising in female roles, sometimes whiten up to look more "feminine". There is a distinct colour line between men and women in this all-female theatrical tradition. One of their features is "Latin shows", in which performers adopt modest dark makeup and dance to Latin music; this form of blacking up is often cited as a symbol of exotic attractiveness in theatrical reviews (Fuchigami 13; "[Takarazuka] The Summer of Passion, to the World of Cats"). Performers who play black characters wear more typical blackface. In 2014, the company staged The Lost Glory: The Beautiful Illusion, a musical adaptation of Othello, written and directed by Ueda Keiko and set in 1920s New York. Otto Goldstein, the Othello character played by Todoroki Yu, was a highly successful Greek immigrant, and Ivano, the Iago character played by Yuzuki Reon, was an illegitimate child of an ItalianAmerican businessman. Todoroki and Yuzuki modestly blacked up for the male roles, while Mishiro Ren, who played the African American servant Sam, wore much darker makeup. For the People: Lincoln, the Man Sought Freedom was produced in 2016, with performers playing African American characters in

\footnotetext{
${ }^{6}$ The publicity photos are available at https://natalie.mu/stage/news/336253
} 
blackface in this highly acclaimed musical biopic. The production was also nominated for the $24^{\text {th }}$ Yomiuri Theatre Award, and reviewers did not mention blackface when the shortlist was published ("The $24^{\text {th }}$ Yomiuri Theatre Award Screening Meeting”). The use of blackface and blacking up in Takarazuka productions, however, has been increasingly criticised in fan blogs, especially after Hamada Masatoshi's blackface incident ("In the First Place, Why Do You Want to Black Up So Much?"; nagi-narico). While the Takarazuka Revue is a prestigious theatre company with over a century's history, some fans think that those traditions need to be updated.

As for the reception of blackface, there is a gap between online criticism and major theatre reviews and awards in Japan. Those who know AngloAmerican theatrical trends are critical of blackface. Other theatregoers, including critics and creators, take blackface for granted because black actors are generally unavailable in Japan.

While one could fault Japanese audiences for their naïveté, it is also important to note that Anglo-American copyright holders, by adopting non-UScentric approaches about race, maintain better creative control over their productions to avoid blackface. The creators of Hairspray, a musical focusing on racism and lookism, know that there are less racially diverse societies in the world than the United States and that people in those regions are also interested in their work. According to the composer, Marc Shaiman, when the copyright holders of the show discussed licensing issues, they first thought that "actors who are the race of the characters" should play the roles but realised that their show might be produced in countries like Japan and Sweden (Kavner). They decided to release a letter insisting that the show never use blackface ("Billing"). This letter was "used as a program note in any production that lacks African American actors" (Wolf 53) until June 2020. Shaiman and his colleagues' decision was an appropriate artistic choice in staging a show problematising racism worldwide.

The Japanese production of Hairspray was to be staged in June 2020, but was eventually cancelled because of the COVID-19 outbreak. Japanese theatregoers were deeply concerned about the blackface problem when the performance schedule was released. Some fans even started a petition against the use of blackface at the beginning of November 2019 (s kanna). Soon after the petition was launched, a Japanese translation of the letter to the audience was uploaded to the official website ("Authors' Letter"). This process illustrated the clear, non-US-centric vision of Hairspray's creative team.

This casting strategy, however, may be changed after the COVID-19 pandemic ends. To respond to the criticism against all-white productions of Hairspray in the midst of the Black Lives Matter movement, Shaiman posted a statement on Instagram saying that he would require "groups to cast the show so as to accurately reflect the characters as we wrote them" (Shaiman). This 
means that only black actors play black roles and white actors play white roles in future productions, perhaps even outside North America. This statement caused anxiety among Japanese fans because they would never be able to see Japanese productions of Hairspray due to the difficulty of finding such actors in East Asian countries.

While the use of blackface had long been unquestioned in Japanese entertainment, theatregoers' frustration has recently grown to the extent that they started a petition against it. This can be ascribed to the increase of black residents in Japan and the popularisation of the Internet, through which fans can obtain information about Anglo-American theatre far more quickly and easily than before. In this cultural climate, Shakespearean productions, long considered high-profile in Japanese theatre, have come to change their attitude towards blackface.

\section{Post-2010 Shakespeare Productions and Race in Japan}

Recently, Japanese productions of Shakespeare have tried to tackle race more frequently than before, using different interpretive strategies. The Setagaya Public Theatre's Othello focused on lookism and male jealousy, Kakushinhan's Othello used acting style to distinguish Othello, and the Shakespeare Company's Ainu Othello changed Othello's race. Comparing these productions with other related productions will enable us to understand the general tendency of Japanese companies' attempt to address race in Shakespeare.

Shirai Akira, an experienced director of translated plays, directed Othello at the Setagaya Public Theatre in June 2013. This production changed the focus from racism to lookism. Nakamura Toru played Othello with no blacking up, Yamada Yu played Desdemona, and Akahori Masaaki played Iago. It downplayed the racial connotations and emphasised Iago's jealousy towards the gorgeous leading couple played by the two popular actors. Othello was deliberately cast as a tall, confident, and genuinely good-looking man, while Iago was portrayed as plain-looking. Although Othello mentioned the racial difference, what mattered more to Iago was the fact that Othello was charming, popular, and successful. Othello's otherness came from his attractive appearance, and Iago's masculine pride was threatened by the handsome outsider. Japanese audience members could easily understand this interpretation. In Japan, there is a popular slang expression, "May all the shiny happy people explode!" It is said that this type of antipathy towards shiny happy people is shared by frustrated heterosexual single men, or Japanese counterparts of American incels (Elliot; Klee; Ueno 61-83). In this production, Iago is something of an incel, although his wife Emilia apparently loves him. Iago is not satisfied with his life and ascribes that to his plain appearance. Instead of 
tackling race, a topic with which Japanese audience members were unfamiliar, this production focused on lookism, alienation, and jealousy, which were more emotionally accessible to a Japanese audience.

This interpretation could be connected to earlier Japanese adaptations of Othello. As Kondo Hiroyuki demonstrates, the first two Japanese novelisations of Othello in the 1890s emphasised Othello's ugliness. Inspired by Othello, Jono Saigiku wrote Abata Denshichiro in 1891, while Udagawa Bunkai wrote Bando Musha in $1892 .{ }^{7}$ Both depicted their Othello characters as ugly. Bando Musha focused on the appearance of Othello, and Kondo calls this novel a "drama of beauty and ugliness" (163). Racism was transformed into lookism, which the late-nineteenth-century Japanese readers could easily understand because they were familiar with the topic through kabuki. As was true in the West, blackness was connected to ugliness in Japan. However, in the Setagaya Public Theatre production, Othello was handsome, and Iago was ugly and envious. Tradition was reversed here, perhaps because the production's creative team strove to highlight Iago's masculine pride.

Kakushinhan, led by director Kimura Ryunosuke, is a theatre company in Tokyo, known for political and modernising interpretations of texts, a physical and violent acting style, and cross-gender casting (Eglinton; Kitamura; Tanaka). In 2015, Kakushinhan staged Othello. Maruyama Atsundo, who played the title role, wore no blackface makeup. What makes Maruyama's Othello different from other characters is the acting style. In an interview I conducted with Kimura on 3 July 2018, he said that it was difficult for Japanese companies to hire black actors. Kimura believed that theatre was for minorities because it challenged the social norms, but that Japanese companies had to take different approaches from English-speaking theatre in order to encourage the audience to understand Shakespeare. Kimura cast actors with "differences" in order to represent the racial "Other" in Shakespeare plays. In Othello, he invited Maruyama from Kara-gumi, a company whose acting style greatly differs from Kakushinhan's. When he directed Titus Andronicus in 2017, Kakushinhan member Iwasaki Mark Yudai played Aaron; he was raised in North America and speaks English, which made a "difference". Physical or linguistic differences signified the "Otherness" in Kakushinhan's productions.

Kakushinhan's decision to distinguish Othello from others by acting style is useful, and when Japanese companies try to signify racial otherness, it is often theatrically effective. In directing an all-male version of The Merchant of Venice in 2013, Ninagawa Yukio hired Ichikawa Ennosuke for Shylock, the only kabuki actor in this production. When AUN Age, the youth branch of Yoshida

7 Abata Denshichiro is included in Shakespeare Translation Literature Collection, vol. 15. Bando Musha was serialised in Mainichi Shimbun from 19 September to 19 October 1982. 
Kotaro's company AUN, staged Othello in 2019, Tanihata Satoshi did not black up in playing the title role; instead, he adopted a kabuki-influenced overacting style.

Ainu Othello was first performed in 2018 by the Shakespeare Company in Sendai, a city in northern Honshu, and toured to Tokyo and London (Yamamoto). This company is famous for performing Shakespeare adaptations in the Tohoku dialect, a north-eastern Japanese accent. Ainu Othello is the first major adaptation featuring Othello as an Ainu man. The Ainu are indigenous people of Japan who live on Hokkaido, the country's northernmost main island. They have suffered from serious discrimination, but their history has been largely ignored by mainstream Japanese (Siddle 6-7). The discrimination against Ainu people is one of worst historical examples of blatant racism in Japan, but no one had ever tried to adapt Othello into a play about them, because the subject was considered too controversial.

Set in 1860, this version depicts Othello as an Ainu general married to Dezuma, a Japanese woman born to a family of samurai in Sendai. According to a post-show talk on 14 June 2018, the director, Shimodate Kazumi, worried about the delicate nature of the story, had invited Akibe Debo, an Ainu artist, to help with the production. The portrayals of Ainu culture in this play, including the Ainu speeches and dancing, were all supervised by Akibe. The handkerchief in the original play was transformed into a matanpushi, an elaborately embroidered headband, which is an important part of traditional Ainu attire. It was an ingenious translation, because audience members who had never heard of matanpushi could easily understand its value just by looking at it, thanks to its refined design. Akibe also advised that Iago should be a half-Ainu, half-Japanese man, because the racial closeness between Othello and Iago would clearly explain Iago's powerful jealousy. Compared to Othello, a valiant general admired by Japanese people, Iago suffers from a different discrimination, because he is despised as a "half-breed" man. Akibe's suggestion gave depth to the production. This production was well received: McNeil said it was "dope" (McNeil).

Like the Setagaya Public Theatre's Othello, Ainu Othello has an important precedent. In Japan, Othello was first performed by Kawakami Otojiro in 1903 as a theatrical adaptation set in Taiwan, translated by Emi Suiin. ${ }^{8}$ In this production, Othello is Muro Washiro, a governor of colonial Taiwan. He is from Satsuma, in the southern part of Japan, and portrayed as a relatively darkskinned character by Kawakami in dark makeup (Tierney 524). Since Muro Washiro is rumoured to come from a "new commoner" (Emi 7), a person from the burakumin class, this adaptation is often regarded as a play dealing with

${ }^{8}$ For this play, see Suzuki 216-219. 
race. ${ }^{9}$ It is an early attempt at changing the racial background of Othello for the Japanese audience. However, this seemingly simple solution did not flourish in Japanese theatre, partly because changing Othello to a minority character in Japan is considered controversial, as the creators of Ainu Othello suggested at the post-show talk. Ainu Othello is a long-awaited successor to the first Othello adaptation in Japan.

Although Ainu Othello addressed racism in a straightforward and careful manner, its treatment of gender was less successful. In contrast to the complex male characters, the female characters were one-dimensional. The dialogues between Dezuma and Emilia were heavily edited, and Emilia's famous speech defending women was cut. Ainu Othello was a bold attempt at highlighting racism in Japan, but it failed to address gender issues.

Several notable attempts have also been made to address race in Japan using Shakespeare. A Strange Tale of Typhoon, a 2015 adaptation of The Tempest set in the 1920s, was written by a Korean playwright, Sung Kiwoong, and directed by a Japanese director, Tada Junnosuke, starkly portraying Japan's colonial past. Chong Wishing, prolific Korean-Japanese playwright and director, produced Macbeth on the Equator in 2018, a backstage drama about Macbeth set in a war criminal prison in post-WWII Singapore, and Crying Romeo and Angry Juliet in 2020, an all-male adaptation of Romeo and Juliet set in post-war Japan and focusing on two mob groups, one led by veterans and the other led by colonial immigrants. These productions have attempted to encourage audience members to discuss racism as something closer to home.

It should be noted, however, that by only focusing on race, creators and viewers may fail to notice another bias in Japanese theatre: gender. Ainu Othello focused too much on male characters. The gendered colour line in the Takarazuka Revue reflects the persisting ideal of beauty in Japan, which predates the contact with the West: white-skinned women are beautiful, while wild and attractive men are darker than women. Crying Romeo and Angry Juliet, an all-male production, unwittingly follows this Takarazuka-style colour line: Juliet is played by a male actor Emoto Tokio without whitening up, and the play contains jokes about Juliet's plainness-based on the assumption that male actors dressed as women without specific makeup are not beautiful, rather, they are problematic.

Japanese theatre companies have gradually learned to address race in Shakespeare, although their approaches still differ notably from those found in English-speaking regions. While blackface is still found on the Japanese stage, the Shakespeare productions discussed in this paper tried to break away from this problematic tradition and present racism more relevant to Japanese

9 See Tierney 523 and Yoshihara 151. For the history of the burakumin's racialization, see Kurokawa. 
viewers by adapting various interpretive strategies. If Japanese companies continues to tackle race and skin colour, however, the concept of beauty and gender must also be questioned in more comprehensive and balanced ways, for these are closely intertwined problems.

\section{WORKS CITED}

"The 24 $4^{\text {th }}$ Yomiuri Theatre Award Screening Meeting: More and More Future Generations of Talents" [第 24 回読売演劇大賞中間選考会 次代担う才 能続々と]. Yomiuri Shimbun [読売新聞], Tokyo ed. 27 July 2016. p. 16.

“The 27 $7^{\text {th }}$ Yomiuri Theatre Award Screening Meeting” [第 27 回読売演劇大賞中間選 考会]. Yomiuri Shimbun [読売新聞], Tokyo ed. 26 July 2019. p. 15.

“Ambitious for the 'Black Transformation”” [「黒い变身」に意欲]. Mainichi Shimbun [毎日新聞], evening ed. 2 March 1973.p. 7.

André, Naomi. Black Opera: History, Power, Engagement. Champaign: University of Illinois Press, 2018.

aru. "Memphis, the Second Viewing" [メンフィス 2 回目]. 4 December 2017. Everyday Life 2 [日常 2]. 21 February 2020. http://ayayay.cocolog-nifty.com/blog/ 2017/12/2-5284.html

“Authors' Letter." November 2020. Hairspray Official Website by Toho Stage. 21 February 2020. https://www.tohostage.com/hairspray/letter.html

"Billing." Music Theatre International http://www.mtishows.co.uk/show-full-billing/1701

Bridges, William H. Playing in the Shadows: Fictions of Race and Blackness in Postwar Japanese Literature. Ann Arbor: University of Michigan Press, 2020.

Eglinton, Mika. "Young Dramatists Mark the Bard's Anniversary in Style." 26 April 2016. The Japan Times. 22 February 2020. https://www.japantimes.co.jp/ culture/2016/04/26/stage/young-dramatists-mark-bards-anniversary-style/\#.XIE EKWj7Q2w

Elliot. "Kakumei-teki Himote Doumei: The Revolutionary Grouping of Men that Women Are Not Attracted To." 9 February 2015. Spoon \& Tamago. 22 February 2020. http://www.spoon-tamago.com/2015/02/09/kakumei-teki-himote-doumeithe-revolutionary-grouping-of-men-that-women-are-not-attracted-to/

Emi, Suiin [江見水蔭], Othello [才セ口], Bumgei Kurabu [文㙯俱樂部] 9 (1903): 1-75. Enterstage Editorial Desk [エンタステージ編集部]. "Memphis the Musical Press Conference! Hamada Mugumi and Other Actors' Hope and Trust in Co-director Yamamoto Koji” [ミュージカル『メンフィス』製作発表！演出も務める 山本耕史に濱田めぐみらが寄せる期待と信頼]. 5 November 2017. Enterstage. 21 February 2020. http://enterstage.jp/news/2017/11/008220.html

Fuchigami, Eriko [淵上えり子]. "[Review of Takarazuka] Flower Troupe, SaintExupéry: An Ingenious Attempt to Shape the Fairy Tale”[[宝塚評]花組「サン ニテグジュペリ」童話の具現化に工夫]. Yomiuri Shimbun [読売新聞], Osaka evening ed. 9 August 2012.p. 13.

Gekipia Editorial Office [げきぴあ編集部]. “An Interview with Jeffrey Page, Director and Choreographer of Memphis the Musical" [ミュージカル『メンフィス』 演出・振付家ジェフリー・ページさんインタビュー]. 29 November 2019. 
Gekipia [げきぴあ ]. 21 February 2020. http://community.pia.jp/stage _pia/2017/11/post-638.html

Hagihara, Yukari [萩原由加里]. “From the Children's Tale to the Cartoon Film: An Essay on "Spider and Tulip" [ [童話から漫画映画へ——『くもとちゅうり つぷ』ついての試論]. Konan-Kokubun [甲南国文] 60 (2013): 320-311.

Holland, Peter. "Shakespeare in the Twentieth-Century Theatre." The Cambridge Companion to Shakespeare. Ed. Margreta de Grazia and Stanley Wells. Cambridge: Cambridge University Press, 2001. 199-216.

"Ichimura Masachika on the Kinokuniya Hall Production with Deep Emotion: 'This Production Exists Because Kusabue Mitsuko Has Joined”’ [市村正親「草笛光 子さんあっての作品」、紀伊國屋ホール出演への感慨語る]. 20 June 2019. Stage Natalie. 21 February 2020. https://natalie.mu/stage/news/336253

Immigration Services Agency [出入国在留管理庁]. “The Population of Non-Japanese Residents in Japan as of the End of June 2019” [令和元年 6 月末現在におけ る在留外国人数について ]. 25 October 2019. Ministry of Justice [法務省]. 21 February 2020. http://www.moj.go.jp/nyuukokukanri/kouhou/nyuukokukanri04 _00083.html

International Fellowship of Regional Music and Culture [国際音楽文化地域交流協会]. “The Perry Black Ship Expedition Musical Journey” [ペリ一黒船音楽紀行]. 29 May 2015. International Fellowship of Regional Music and Culture. 21 February 2020. http://rmac.jp/motion/motion02.html

“In the First Place, Why Do You Want to Black Up So Much?”[そもそも、なんでそ こまで黒塗りしたいの? ]. 6 January 2018. Hatelabo: AnonymousDiary. 22 February 2020. https://anond.hatelabo.jp/20180106164019

"Japanese TV Show Featuring Blackface Actor Sparks Anger." 4 January 2018. BBC.

21 February 2020. https://www.bbc.com/news/world-asia-42561815

Kavner, Lukas. "All-White Production Of 'Hairspray' In Texas Raises Eyebrows."

1 February 2012. Huffington Post. 21 February 2020. https://www.huffpost. com/entry/all-white-production-of-h_n_1244955

Kitamura, Sae. "Hamlet by Kakushinhan." Shakespeare Studies [in Japan] 54 (2016): $72-74$.

Klee, Miles. "Japanese Incels Are Fighting for a Marxist Revolution.” 2019. Melmagazine. 22 February 2020. https://melmagazine.com/en-us/story/japanese-incels-marxistrevolution-kakumeiteki-himote

Kodama, Shoko [小玉祥子]. “Othello Featuring Sato Chikau” [佐藤誓主演「オ七ロー」]. Mainichi Shimbun [毎日新聞], evening ed. 28 June 1999. p. 7.

Kondo, Hiroyuki [近藤弘幸]. “Othello 'De-Colourised': Udagawa Bunkai's Bando Musha (1892)” [脱「色」された『オ七ロ一』——宇田川文海『阪東武者』 (一八九二) ], The Japan Shakespeare Society [日本シェイクスピア協会], ed., Shakespeare and Theatre Culture: The Japan Shakespeare Society $50^{\text {th }}$ Memorial Essays [シェイクスピアと演劇文化一一日本シェイクスピア協 会創立五 $\bigcirc$ 周年記念論集]. Tokyo: Kenkyusha [研究社], 2012: 158-179.

Kurokawa, Midori [黒川みどり]. The Created Race: Buraku Discrimination and Racism [創られた「人種」———部落差別と人種主義], Yushisya [有志社], 2016. 
Maruya, Kyubee [丸屋九兵衛]. “Article 18: A Variation of Black \& White. Kao ‘\#Bewhite' and the Birth of Black Ichimura Masachika” [第 18 回: ブラック \&ホワイトをめぐる変奏曲。花王「\#BeWHITE」と黒い市村正親の誕 生 ]. 11 July 2019. Chikuma Web. 21 February 2020. http://www. webchikuma.jp/articles/-/1776

Matsumoto, Hisashi [松本尚史]. “Settlement and Transnational Movement among African Migrants in Japan: Through the Case Study on Economic Activities among the Igbos from Nigeria”[在日アフリカ人の定住化とトランスナシ ヨナルな移動——ナイジェリア出身者の経済活動を通して]. The Journal of African Studies [アフリカ研究] 85 (2014): 1-12.

McNeil, Baye. "To Black Up or Not to Black Up for 'Othello,' That Is the Question." 16 September 2018. The Japan Times. 22 February 2020. https://www. japantimes.co.jp/community/2018/09/16/our-lives/black-not-black-othelloquestion\#.X1EX3Gj7Q2w

Mori, Kazuo. "Assessment of the Implicit Attitude of Japanese People toward Blacks and Little Black Sambo." Open Journal of Social Sciences 6 (2018): 1-13.

nagi-narico. "Blackface in Theatre and 'Cultural Appropriation'” [演劇におけるブラッ クフェイス問題と「Cultural appropriation」について。]. 8 Mach 2018. Entrevue Blog. 22 February 2020. https://nagi-narico.hatenablog.com/ entry/2018/03/03/120000

Office for National Statistics. "Ethnicity and National Identity in England and Wales: 2011.” 11 December 2012. Office for National Statistics. 21 February 2020. https://www.ons.gov.uk/peoplepopulationandcommunity/culturalidentity/ethnic ity/articles/ethnicityandnationalidentityinenglandandwales/2012-12-11

Osaki, Tomohiro. "Fuji TV Removes Blackface Segment after Outcry." 9 March 2015.

The Japan Times. 21 February 2020. https://www.japantimes.co.jp/news/ 2015/03/09/national/fuji-tv-removes-blackface-segment-after-outcry/\#.Xk6D1 mj7Q2x

Sato Toshiaki [佐藤利明]. “Enoken in Film: Collaboration with Director Yamamoto Kajiro”[映画のなかのエノケンー一山本嘉次郎監督とのコラボレーショ ン]. Enoken and the Golden Age of “Tokyo Comedy” [エノケンとく東京喜劇 $>$ の黄金時代]. Ed. Tokyo Kigeki Kenkyukai. Tokyo: Ronsosha [論創社], 2003. 42-83.

Shakespeare Translation Literature Collection [シェイクスピア翻訳文学書全集]. 45 vols. Tokyo: Ozorasha [大空社], 1999-2000.

Shaiman, Marc [@marc_shaiman]. "Hello, @marc_shaiman here.”3 June 2020. Instagram. 18 October 2020. https://www.instagram.com/p/CA8jODfjcH6/c/ 17889213685543125/

Siddle, Richard. Race, Resistance and the Ainu of Japan. Abingdon: Routledge, 2001. s kana. "Please Avoid Blackface in Hairspray the Musical” [ミュージカル「ヘアスプ レー」でブラックフェイスをするのはやめてください]. November 2019. Change.org. 21 February 2020. https://www.change.org/p/\%E6\%9D\%B1\% E5\%AE\%9D\%E6\%A0\%AA\%E5\%BC\%8F\%E4\%BC\%9A\%Е7\%A4\%BE$\%$ E3\%83\%9F\%Е3\%83\%A5\%Е3\%83\%BC\%Е3\%82\%B8\%Е3\%82\%AB\% E3\%83\%AB-\%E3\%83\%98\%E3\%82\%A2\%E3\%82\%B9\%Е3\%83\%97\%E3\% $83 \%$ AC\%Е3\% $83 \%$ BC-\%Е3\%81\%A7\%Е3\%83\%96\%Е3\%83\%A9\%Е3\%83\% 83\%E3\%82\%AF\%E3\%83\%95\%E3\%82\%A7\%E3\%82\%A4\%E3\%82\%B9\%E3 
\%82\%92\%E3\%81\%99\%E3\%82\%8B\%E3\%81\%AE\%E3\%81\%AF\%E3\%82\%8 $4 \% \mathrm{E} 3 \% 82 \% 81 \% \mathrm{E} 3 \% 81 \% \mathrm{~A} 6 \% \mathrm{E} 3 \% 81 \% 8 \mathrm{~F} \% \mathrm{E} 3 \% 81 \% \mathrm{~A} 0 \% \mathrm{E} 3 \% 81 \% 95 \% \mathrm{E} 3 \%$ $81 \% 84$

Suematsu, Michiko [末松美知子]. "Relocation of the Setting in Othello: Comparison of British and Japanese Productions since the 1980s”[『オセロ』上演における舞 台設定——1980 年代以降の日英の上演を中心に]. Gunma University Journal of Social and Information Studies『群馬大学社会情報学部研究論集』 12 (2005): 13-21.

Suzuki, Krys, and Jay Allen. "Blackface in Japan: Its History-And Its Consequences". 26 November 2019. Medium. 21 February 2020. https://medium.com/@ unseenjapan/blackface-in-japan-its-history-and-its-consequences-af4f57c97300

Suzuki, Masae. "Who Are the Japanese Othellos? Reception and Productions of Shakespeare in Mainland Japan and Okinawa." Annals of Kyoto Sangyo University: Humanities [京都産業大学論集人文科学系列]. 31 (2004): 215-228.

“[Takarazuka] The Summer of Passion, to the World of Cats: Snow Troupe's Gato Bonito!!”[宝塚]情熱の夏＼cjkstart猫の世界へ 雪組「Gato Bonito!!」]. 18 June 2018. Yomiuri Shimbun [読売新聞], Osaka evening ed. 18 June 2018, p. 7.

Tanaka, Nobuko. “Kimura's Crazed 'Macbeth' for Today”. 24 January 2017. The Japan Times. 22 February 2020. https://www.japantimes.co.jp/culture/2017/01/24/ stage/kimuras-crazed-macbeth-today/\#.XIEEKmj7Q2w

Thompson, Ayanna. Passing Strange: Shakespeare, Race, and Contemporary America. Oxford: Oxford University Press, 2011.

Tierney, Robert. "Othello in Tokyo: Performing Race and Empire in 1903 Japan." Shakespeare Quarterly 62 (2011): 514-540.

Udagawa, Bunkai [宇田川文海]. Bando Musha [阪東武者]. Mainichi Shimbun [毎日新 聞]. 19 September 1892-19 October 1982. 32 episodes.

Ueno, Chizuko [上野千鶴子]. Woman Hating: Misogyny in Japan [女ぎらい——ニッ ポンのミソジニー]. Asahi Shimbun Shuppansya [朝日新聞出版社], 2018.

United States Census Bureau. "QuickFacts: United States.” 1 July 2019. United States Census Bureau. 6 December 2020. https://www.census.gov/quickfacts/fact/ table/US/PST045219

Vaughn, Virginia Mason. Performing Blackness on English Stages, 1500-1800. Cambridge: Cambridge University Press, 2005.

Wolf, Stacy. Beyond Broadway: The Pleasure and Promise of Musical Theatre Across America. Oxford: Oxford University Press, 2019.

Yamamoto, Issei. "'Othello' to Hit London Stage, Focusing on Ainu Discrimination." 6 July 2019. The Asahi Shimbun. 22 February 2020. http://www.asahi. com/ajw/articles/AJ201907060001.html

Yellin, Victor Fell. "Mrs. Belmont, Matthew Perry, and the 'Japanese Minstrels."' American Music 14.3 (1996): 257-275.

Yoshihara, Yukari. "“Raw-Savage" Othello: The First Staged Japanese Adaptation of Othello (1903) and Japanese Colonialism." Shakespeare and the Ethics of Appropriation. Ed. Alexa Huang and Elizabeth Rivlin. Palgrave Macmillan, 2014. 145-160. 